\title{
Fiscal Decentralization with a Redistribution Rule vs. Fiscal Centralization
}

\author{
Zeynep Burcu BULUT-ÇEVIK (https://orcid.org/0000-0002-3318-1122), Department of Public Finance,
} Ankara Ylldırtm Beyazıt University, Turkey; e-mail: zbcevik@ybu.edu.tr

\section{Mali Merkezîleşme ile Yeniden Dağıtım Kuralı altında Mali Yerelleşmenin Karşılaştırılması}

\begin{abstract}
This paper compares the case of fiscal decentralization (FD) with an intergovernmental transfer rule to the case of fiscal centralization (FC) from a theoretical perspective while focusing on Markovperfect Nash equilibrium by a continuum of citizens, local governments and a central government, which interact strategically. Simulation analysis shows that both the degree of spillovers and capital mobility play a role in the comparison of these two cases. In the presence of spillovers, the welfare of FD case is higher than the one of FC which is an unexpected result but points out the positive effect of a redistribution rule in FD model in terms of welfare. On the other hand, the growth rate of FD is lower than the FC case when there are spillovers. So, fiscal discipline, provided by the redistribution rule, prevents inefficiently low tax rates which pull down the growth rate. In addition, when spillovers are not allowed, capital mobility determines which case is superior.
\end{abstract}

Keywords

Fiscal Decentralization, Fiscal Centralization, Intergovernmental Transfer/ Redistribution Rule, Welfare, Capital Mobility.

JEL Classification Codes : $\quad$ H77, H23, O41, C63, C72.

Öz

Bu çalışma, yönetimlerarası transfer kuralına sahip mali yerelleşme ile mali merkezîleşmenin teorik perspektiften karşılaştırmasını yapmaktadır. Vatandaşların, yerel yönetimlerin ve merkezi hükümetin stratejik olarak etkileşimde olduğu bu modelde Markov-perfect Nash dengesi üzerinde çalışılmıştır. Simülasyon analizleri, yayılma (spillovers) derecesinin ve sermaye hareketliliğinin bu karşılaştırmada etkili olduğunu göstermiştir. Yayılmanın olduğu durumda, mali yerelleşmede görülen refah seviyesinin mali merkezîleşmeden yüksek olduğu görülmüştür. Bu durum beklenmeyen bir sonuç olmasına karşın, transfer kuralının mali yerelleşmeye refah açısından olumlu etkisine işaret etmektedir. Diğer yandan, yayılmanın olması halinde, mali yerelleşme durumunda büyümenin mali merkezîleşmeden düşük olduğu gözlenmiştir. Bu durum, transfer kuralı ile ortaya konan mali disiplinde hedeflenen vergi oranının, çok altına düşememesi sebebiyle büyümenin de yükselmesinin engellendiği sonucuna varılabilir. Yayılmanın olmaması durumunda ise, durumların birbiri üzerindeki üstünlüğünü belirleyenin sermaye hareketliliği olduğu bulunmuştur.

Anahtar Sözcükler : Mali Yerelleşme, Mali Merkezîleşme, Yönetimlerarası Transfer/ Yeniden Dağıtım Kuralı, Refah, Sermaye Hareketliliği. 


\section{Introduction}

Fiscal decentralization (FD) refers to "the devolution of fiscal powers from national government to subnational governments". The necessity of introducing FD comes from facilitating the fiscal duties of the government, which is assumed to conclude with the efficient allocation of resources. Although the logic of the FD is firstly introduced to the literature by Tiebout (1956), extensive research about FD has conducted along with the seminal work of Oates (1972). This work focuses largely on the economic effects of FD and reasons behind the tendency to FD among developed countries by comparing centralized and decentralized fiscal systems.

There is a wide literature discussing the advantages and disadvantages of FD and fiscal centralization (FC) both theoretically and empirically. The motivation of the most empirical studies arises with the tendency towards FD among developed countries, so that they focus on whether there exists a relationship between growth and FD. On the other hand, theoretical studies investigate not only growth but also welfare effects of FD from different perspectives. One perspective is related to the political economy point of view ${ }^{1}$. For instance, Besley and Coate (2003) compare decentralized and centralized fiscal systems through this perspective. They show the existence of a threshold level of public good spillovers with different choices of legislature where FD or FC yields higher welfare level than the other one. The other perspective is investigating the welfare consequences of tax competition and tax coordination (or harmonization) among localities, states or countries ${ }^{2}$. Arguments about the economic effect of tax competition to the economy have been widely discussed and not reached an agreed decision yet, but most of the studies in this literature argue that inefficient level of public good provision is observed due to low levels of the tax rate. (Bradford and Oates, 1971; Oates, 1972; Rohac, 2006; Brueckner, 2003). In this paper, we include tax competition in our model with some political economy-related variables to be the part of these discussions while our research question is investigating the growth and welfare comparisons for the cases of FD and FC with some specific properties ${ }^{3}$.

One of the properties in our model is to include intergovernmental transfers into the FD model. Some studies related to decentralized fiscal systems highlight the importance of intergovernmental fiscal systems. The necessities of intergovernmental transfers emerge from vertical and horizontal fiscal imbalances. These fiscal imbalances occur due to the mismatch of local government expenditure and revenue and in order to remove these, intergovernmental transfers are widely used by the governments. Although they are widely preferred, they may cause some problems such as moral hazard problem since local governments identify them as an insurance against their poor decisions, which creates moral

\footnotetext{
See Lockwood (2006) for a review.

Razin and Sadki (1991); Zodrow (2003); Keen (1993).

These properties are discussed in the model part in detail.
} 
hazard problem. Fiscal indiscipline can be counted as another problem in distributing transfers due to common pool problem, soft financing and grant design (Eyraud \& Lusinyan, 2011). Hence designing a transfer mechanism or rule 4 should be crucial to make it effective. Ma (1997) and Shah (1995) claim that effective intergovernmental transfers should have some specific properties such as: revenue adequacy, local tax effort, equity, transparency and stability. However, in most of the theoretical models, other than lump sum transfers, intergovernmental transfer rules or mechanisms, which have some of these properties, are omitted. On the other hand, in particular, Akin et al. (2016) proposes a linear redistribution rule, which aim to correct for the income and tax collection effort differences among jurisdictions, in a static model. Their objective is to observe the effect of FD with a predetermined transfer rule on fiscal discipline compared to the effect of FC. They find that FD with the transfer rule positively affects the fiscal discipline, but income distribution worsens compared to the centralized system. This study also uses this linear transfer rule with a slight difference; instead of tax collection effort, used to represent efficiency property, we introduce tax revenue and tax revenue target for each locality. This change does not affect the fact that it still represents the efficiency property, since it also shows how much tax revenue is collected compared to the target for that locality as in the case of measuring the tax collection effort deviation.

Another debated topic in FD literature is the utility structure of local governments. Local governments, which maximize the local welfare of its citizens, are called 'Pigouvian' governments. (Zodrow \& Mieszkowski, 1986) On the other hand, Brennan and Buchanan (1980) define governments as pure rent-seekers, who provide public goods with the expectation to collect rents for themselves and call them 'Leviathan' governments. Edwards and Keen (1996) find that if governments are not fully self-serving, but partly benevolent then desirable levels of policy variables are observed. Rauscher (1998) also uses this kind of government (neither fully benevolent nor fully self-caring) in his studies to show that inter-jurisdictional competition for mobile factors of production forces the government to raise the efficiency of the public sector. In addition, Epple and Nechyba (2004) compare these two extreme models of local government behavior from local tax rates and public good levels and conclude that both not fully selfish and not fully benevolent government gives desired levels of tax rate and public good simultaneously. This study takes into account these discussions and introduces political economy variables, rent-seeking variable and degree of selfishness of the local government ${ }^{5}$, into the utility form of the government. This utility form allows the local governments to be fully benevolent, fully selfish or between these two.

This paper extends the literature as follows. In fiscally decentralized theoretical models, transfer rule or mechanism is mostly missing, other than lump-sum transfers as

4 Transfer rule, intergovernmental transfer rule and redistribution rule represent the same idea and so are used interchangeably throughout this study.

5 Rent seeking variable is denoted as ' $R$ ' and selfishness of the politician as ' $L$ ' in the paper and will be explained in detail in the model section. 
stated before, where Ma (1997) and Shah (1995) argue insufficiency of lump-sum transfers in observing the effects of FD on the economy and highlight the significance of a welldesigned redistribution rule. This study tries to fill this gap by focusing on how the inclusion of a linear transfer rule affects the comparison of fiscally decentralized and centralized systems from a theoretical perspective. To be able to use a transfer mechanism as a linear constraint in our government's problem, this study includes equity and local tax effort, in the name of efficiency, properties in decentralized fiscal case. Secondly, most of the theoretical FD models do not include central government but only local governments since in decentralized fiscal systems, the main fiscal decision makers are the local governments. However, even in the most decentralized fiscal systems such as US, Canada, etc., central government detects and controls the actions of local governments and if necessary, it takes actions in order to maintain the stability, equity or efficiency of the overall economy. This study does not ignore this argument and incorporates a central government, which controls local governments through a redistribution rule, where local governments are the main fiscal executives in the case of FD of this study. Hence, there will be a 3-stage game in the decentralized fiscal system.

The present paper is designed to investigate and compare the growth and welfare effects of FD and FC. The model has some similarities with the Chu and Yang's (2012) endogenous growth model as well as the redistribution system that was firstly constructed by Akin et al. (2016) in the literature. The model of Chu and Yang (2012) can be considered as an extension of Besley and Coate's (2003) public provision model. In Besley and Coate's model, the public good provision model is in the static form without tax competition as well as the model of Akin et al. (2016). The model of Chu and Yang (2012) is a dynamic endogenous growth model with the allowance of tax competition and public good spillovers. They examine differences between FD and FC via this endogenous growth model. They show the dominating effect of FD in growth over FC, but in welfare, the superiority depends on capital mobility level. The main difference between their model and the current model is the redistribution mechanism that Wilson (1999) claims as a necessary procedure if tax competition exists in the model. In addition, the political economy point of view is limited to interpreting the degree of rent-seeking variable with selfishness parameter.

In the decentralized case, local governments choose their policy independently, simultaneously but non-cooperatively for each point in time $t$. There is a central government that has no role in fiscal policy only determines the redistribution. Local governments cannot internalize public good spillovers but there exists tax competition since each locality chooses his own tax rate at each time $t$. After central government decides transfers, local governments maximize their lifetime utility and then citizens maximize their own lifetime utility subject to flow budget constraint. In the case of centralized system, there are local governments that have no role in fiscal policy because they are assumed to coordinate each other and symmetric. Local governments only get transfers from central government and use it for local expenses. Since central government coordinates the fiscal policy and set a fixed tax rate for all jurisdictions, the spillovers of public goods are internalized across jurisdictions. In other words, there is no tax competition. After the central government decides on fiscal policy, citizens maximize their own lifetime utility subject to flow budget constraint. 
Analytical solutions can be found for both cases (FD and FC), however, because of the complexity of the results, comparisons between decentralized and centralized cases need simulation analysis. In welfare comparisons, the effects of spillovers and capital mobility play significant roles. Most of the theoretical FD studies ${ }^{6}$ argue that FD provides higher growth but lower welfare levels than FC, but in these studies, redistribution mechanism is mentioned but omitted. So, introducing redistribution rule may lead to unexpected results than these studies or than Decentralization Theorem. For instance, when there are spillovers among governments, FD with redistribution rule provides higher welfare than FC even tax rate is higher in case of FD than FC. So, lower tax rate in FC model means lower tax revenue, which lessens the utility levels of citizens since the utility of citizens is composed of private consumption, home public good and neighbor public good levels. However, this comparison changes with respect to the level of capital mobility when there are no spillovers. In case of low mobility, the decentralized case has a higher welfare level than the centralized case. On the other hand, in case of high capital mobility, FC provides higher welfare than FD. These findings show the corrective effect of a redistribution rule, which takes into account equity and efficiency, in fiscally decentralized economies. In other words, fiscally decentralized economies may avoid the disadvantages of being decentralized compared to being centralized by introducing a linear redistribution rule, which has equity and efficiency properties, according to the welfare level comparisons. Hence, the results of welfare comparisons may seem so different from the Decentralization Theorem, however in decentralization theorem, there is not intergovernmental transfer system which may affect the whole theorem if included. This study shows how Decentralization Theorem may differ when a linear transfer rule is introduced to the decentralized fiscal model.

Another result, related to growth rate comparisons, also depends on the existence of spillovers. The growth rate in the decentralized case with redistribution rule is lower than the rate in the centralized case when there are spillovers. So, with the existence of spillovers, fiscal discipline, provided by the redistribution rule, prevents inefficiently low tax rates, which pull down the growth rate.

The organization of this paper is as follows: Section 2 introduces the model then Section 3 reports the results of the model. The final section, Section 4, provides the overall summary and conclusions.

\section{The Model}

In our model, there are three agents, interacting with each other. These agents are citizens, local governments, and a central government. Time is continuous. Tax competition between local governments and public good spillovers across regions are allowed. In order to reduce the complexity while providing endogenous growth, A-K type endogenous growth 
model is preferred. We assume that capital is mobile, and its income is the only revenue source for the government.

In this study, the differences between FD and FC are based on the authority of fiscal policy. In FD, local governments are in charge of fiscal policy whereas, in FC, the central government is the only authority. The main difference of this model than already existing models in the literature is including a linear redistribution rule with tax competition and public good spillovers to the FD case, and examining how different the results are than Decentralization Theorem and which mechanism makes the difference.

In the decentralized fiscal set up, central government only distributes tax revenue, which local government collects, according to a linear redistribution rule. With this transfer, local governments (LGs) choose their policy independently, simultaneously but noncooperatively for each point in time t. Local governments cannot internalize public good spillovers but there exists tax competition since each locality chooses his own tax rate at each time t. After central government (CG) decides transfer amounts that each locality takes, local governments maximize their lifetime utility and then citizens maximize their own lifetime utility subject to flow budget constraint.

In the centralized set up, there are LGs but has no role in fiscal policy because they are assumed to coordinate each other and symmetric. They only get transfers from CG and use it for local expenses. Since CG coordinates the fiscal policy and set a fixed tax rate for all jurisdictions, the spillovers of public goods are internalized across jurisdictions. (i.e. no tax competition) After $\mathrm{CG}$ decides the fiscal policy, citizens maximize their own lifetime utility subject to flow budget constraint.

After briefly explaining the FD and FC set ups in the preceding paragraphs, the agents and their characteristics are explained in the coming subsections in detail.

\subsection{Citizens}

Citizens are identical, living in geographically distinct but symmetric districts. For simplicity, two jurisdictions are assumed to exist: home and neighbor jurisdictions. Citizens ${ }^{7}$ typically maximize their utility subject to flow budget constraint. It is a dynamic model with an allowance of public good spillovers. * is used to denote neighbor variables.

The lifetime utility of citizens in each jurisdiction is represented by

$$
\mathrm{U}=\int_{0}^{\infty} \mathrm{e}^{-\rho \mathrm{t}}\left[\ln \mathrm{C}_{\mathrm{t}}+(1-\mathrm{s}) \ln \mathrm{G}_{\mathrm{t}}+\mathrm{s} \ln \mathrm{G}_{\mathrm{t}}^{*}\right] \mathrm{dt}
$$


where $\rho>0$ is a discount factor, $C_{t}$ is the level of consumption, $G_{t}$ is the level of local public goods in the home jurisdiction at time $t$ and $G_{t}^{*}$ is the level of local public goods in the neighbor jurisdiction at time t. $s \in[0,0.5]$ is the degree of positive spillovers: $s=0$ means that the citizen only care about the public good provided in home jurisdiction. It is assumed that the public good at neighbor jurisdiction cannot affect the citizen more than the public good at home jurisdiction since the citizen is living in the home jurisdiction. In addition, the public good at neighbor jurisdiction cannot affect the citizen's well-being negatively since the citizens are assumed to be rational, in other words, the citizen will prefer not to use the neighbor's public good at all, other than getting negative utility. The idea of this set-up is similar with Besley and Coate's (2003) public good provision model with the same range of positive spillover degree.

In this model, agents are not allowed to move but capital is mobile and taxed, so tax competition is observed under mobile capital. Due to the mobility of capital, there are different levels of capital for two jurisdictions. The capital level distributed to the home locality is denoted as $D_{t}$, whereas the capital level distributed to the other neighbor locality is denoted as $F_{t}$ so that the total amount of capital is $K_{t}=D_{t}+F_{t}$. The total amount of tax paid by the citizen living in home jurisdiction to the government is $\tau_{t} i D_{t}+\tau_{t}^{*} i^{*} F_{t}$ at time $t$. The ratio of capital allocated to neighbor jurisdiction over total capital is denoted by $\theta_{t}=$ $F_{t} /_{K_{t}}$ so $1-\theta_{t}=D_{t} /_{K_{t}}$ is the ratio of capital allocated to the home jurisdiction over total capital per citizen at time $t .{ }^{8}$ This construction leads to a constraint, which is:

$\theta_{t} \in[0,1]$

Citizens choose their saving and consumption amounts while aiming to maximize their lifetime utility subject to flow budget constraint, which is ${ }^{9}$ :

$$
\dot{K}_{t}=\left(1-\tau_{t}\right) i D_{t}+\left(1-\tau_{t}^{*}\right) i^{*} F_{t}-C_{t}-M\left(\theta_{t}, K_{t}, m\right)
$$

where $\mathrm{C}_{\mathrm{t}}$ is the level of consumption, $K_{t}$ is the total capital level belonging to the citizen, residing in home jurisdiction, $D_{t}$ is the capital level allocated to home jurisdiction and $F_{t}$ is the capital level allocated to foreign jurisdiction. In addition, $\tau_{t}$ is the tax rate levied on each unit of capital at home jurisdiction, $\tau_{t}{ }^{*}$ is the tax rate levied on each unit of capital at neighbor jurisdiction at time $\mathrm{t}$ and $i$ is the rental rate of return at home whereas $i^{*}$ is the rental rate of return in neighbor jurisdiction.

8 The same equalities hold for the citizens, living in the neighbor jurisdiction. In other words, the capital level distributed to the neighbor locality is denoted as $D_{t}{ }^{*}$, whereas the capital level distributed to the home locality is denoted as $F_{t}{ }^{*}$ so that the total amount of capital is $K_{t}{ }^{*}=D_{t}{ }^{*}+F_{t}{ }^{*}$. So, $D_{t}{ }^{*}$ does not have to be equal to $D_{t}$.

9 Depreciation of the capital is widely introduced in growth models, however in order to reduce the complexity of the model, depreciation of the capital is omitted in this study since it is out of the scope for this paper. 
The last term in budget constraint is the cost of investing in neighbor jurisdiction instead of home jurisdiction. It represents all the possible uncertainties and risks coming with the investing abroad. The functional form is similar to the ones in the papers of Persson and Tabellini (1992), Lejour and Verb (1997) and Chu and Yang (2012). The form of the cost function is as follows:

$$
M\left(\theta_{t}, K_{t}, m\right)=K_{t}\left(\theta_{t}\right)^{2} / m
$$

where $m \in(0, \infty)$ is the degree of capital mobility. If $m=\infty$, i.e. the capital is perfectly mobile, then there will be no cost, however if $m=0$, i.e. the capital is perfectly immobile, then the cost will go to infinity which means it is not rational to move the capital. As will be shown in the coming section, the higher the degree of capital mobility, the lower the tax rate is. ${ }^{10}$ Costly implementation of capital flight for citizens explains the increasing property of cost function, whereas convexity property implies marginal cost increases as the size of capital flight increases.

\subsection{Firms}

The owners of the firms are the households and each firm aims to maximize its profit and chooses how much to produce. In other words, a firm solves the following problem:

$$
\max _{K_{t}} \pi=F\left(K_{t}\right)-i K_{t}
$$

Solution of the problem with A-K type production function is ${ }^{11}$

$$
F^{\prime}\left(K_{t}\right)=i=A
$$

So, the rental rate of the firm is equal to the technology level of the locality. Since the localities are symmetric (i.e. they have similar properties such as technology level) and firms in the neighbor jurisdiction also solve the same problem, the rental rate of each locality will also be equal to each other:

$$
i=i^{*}
$$

10 Deveraux et al. (2008) find out loosening capital controls decrease the corporate tax rate in OECD countries in 1980s and 1990s. Winner (2005) argues that capital mobility decreases the capital tax burdens in OECD countries.

11 The profit coming from the firm is zero. Also, the reason behind the choice of AK type production function is introducing endogenous growth to the model while having a tractable type of production function. 


\subsection{Governments}

There are two types of government: LGs and CG, and the roles differ significantly both in decentralized and centralized case. Because of these differences, governments will be explained case by case.

\subsubsection{Local Government (LG)}

\subsubsection{Decentralized Case}

Brennan and Buchanan (1980) criticize 'Pigouvian' type governments and propose 'Leviathan' type governments. He declares that since politicians run governments, governments are pure rent seekers. With this idea, policy-making governments may be fully selfish or fully benevolent or between these two in this study. How the politicians are selected or why is not this study's concern so the political economy part is mostly missing. However, allowing using some portion of the tax revenue for politician's self-interested purposes makes the governments not fully benevolent. (Lockwood, 2006) LG maximizes his lifetime utility subject to the law of motion for capital and instantaneous balanced budget constraint.

The lifetime utility is as follows:

$$
V=(1-L)\left(\int_{0}^{\infty} \mathrm{e}^{-\rho \mathrm{t}}\left[\ln \mathrm{C}_{\mathrm{t}}+(1-\mathrm{s}) \ln \mathrm{G}_{\mathrm{t}}+\mathrm{s} \ln \mathrm{G}_{\mathrm{t}}^{*}\right] \mathrm{dt}\right)+L\left(\int_{0}^{\infty} e^{-\rho t}\left[\ln R_{t}\right]\right)
$$

where $U$ is the lifetime utility of a citizen and $R_{t}$ is the amount of tax revenue that is used for self interested purposes by politicians at time $t . L \in[0,1]$ is given exogenously ${ }^{12}$ which represents the degree of selfishness of the politician, also known as rent seeking parameter (Lockwood, 2006; Edwards and Keen, 1996: Rauscher, 1998). If $L=0$, the government does not use any tax revenue for his self-interested purposes, so the government gets utility only from the utility of citizens, i.e, the government is fully benevolent. If $L=1$, the government does not care about the citizen's utility, only cares about his own purposes, i.e. the politician is fully selfish.

There is a balanced budget constraint, that should hold for each point in time, $t$. It is as follows:

$$
G_{t}+R_{t}=N_{t}
$$

where $\mathrm{N}_{\mathrm{t}}$ is the amount of transfers sent by CG. The source of these transfers is tax revenue, collected by LGs. The interpretation of this equation is that government use transfers either

12 The degree of the selfishness of the politician, L, can also be endogenously determined, however in that case there will no benefit for this study's research question but only complicates the model. 
for the public good provision or for its own political concerns. The transfer amount is decided with a rule by $\mathrm{CG}$.

Given citizen's best response, the LG chooses fiscal policy variables, which are tax rate, rents, and public goods by maximizing lifetime utility of the politician (equation 3 ) with respect to the law of motion for capital (equation 2) and budget constraint (equation 4).

\subsubsection{Centralized Case}

As stated before, in centralized case, $\mathrm{CG}$ is the main decision maker in fiscal policy and LGs have no role. They only get the transfers from the CG and distribute it. In other words, there is no choice or optimization problem for LGs in centralized case. There is only one type of government, $\mathrm{CG}$, in centralized case.

\subsubsection{Central Government (CG)}

\subsubsection{Decentralized Case:}

In this study, for simplicity, it is assumed to exist only two geographically distinct but symmetric localities. And the objective function of $\mathrm{CG}$ is the utilities of these localities. So CG maximizes lifetime utilities of both localities with respect to lifetime balanced budget constraint. The objective function is as follows:

$$
\mathrm{U}+\mathrm{U}^{*}
$$

where $U$ is the lifetime utility of a citizen and in the form of (1). $U^{*}$ is the lifetime utility of the other locality's citizen with the same form.

Assume there is a common pool, that all the localities drop their tax revenue into that pool and there exists a superior unit, which is central government. It decides which locality should get how much tax revenue from that pool. CG is assumed to be fully benevolent. This common pool can be represented as ${ }^{13}$ :

$$
A \tau_{t} K_{t}+A \tau_{t}^{*} K_{t}^{*}=N_{t}+N_{t}^{*}
$$

CG does not directly decide the transfer amounts since there is a redistribution rule.

In the literature, the transfer mechanism is known as balancing tool between government entities. In this study, the redistribution rule is similar to Akin et.al. (2016), however there exists a slight difference. Akin et.al. (2016) focus on tax collection effort, but

13 From the firm problem, it is known that the rental rate of a locality is equal to the technology level and due to symmetricity of localities, technology levels and rental rates of localities are both equal to each other. With this knowledge, the left-hand side of the equation (6) is derived. 
in this study tax revenue levels and targets are defined and used. In this rule, there are two basic parts: efficiency and equity. Efficiency part aims the fiscal discipline by targeting the tax revenue. Equity part aims to destroy the horizontal imbalances between localities.

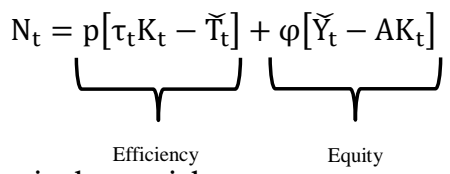

where $\mathrm{p}$ is the punishment parameter and $\gamma$ is the income compensation parameter, $\widetilde{\mathrm{T}}_{\mathrm{t}}$ is the tax revenue target level and $\widetilde{Y}_{t}$ is the income target level that are set exogenously. For instance, if a locality cannot reach tax revenue target level then $\mathrm{CG}$ punishes the locality and decreases the transfer amount with a degree of $\mathrm{p}$. Also, if a locality cannot reach the income target level then CG increases the transfer amount with a degree of $\gamma$ in order to decrease the horizontal imbalances.

The former part, $\mathrm{p}\left[\tau_{\mathrm{t}} \mathrm{K}_{\mathrm{t}}-\widetilde{\mathrm{T}}_{\mathrm{t}}\right]$, is the efficiency part since unless locality can collect its potential amount of tax revenue, it is punished with decreasing transfers. In other words, efficiency part provides the fiscal discipline by targeting the tax revenue level. The latter part, $\varphi\left[\widetilde{Y}_{t}-\mathrm{AK}_{\mathrm{t}}\right]$, is the equity part since the aim of this equation is equalization among localities in terms of their income levels. In other words, equity part decreases the horizontal imbalances between localities.

For the current case, $\mathrm{CG}$ is not involved in fiscal policy decisions, its role is only determining the parameter values in redistribution rule, so that, it decides the amounts of the transfers indirectly. Hence, CG maximizes (5) subject to (6) and (7) to determine p and $\gamma$.

\subsubsection{Centralized Case}

The problem of CG is similar to the problem of LG in decentralized case since the fiscal policy decision maker is CG in centralized case and it is LG in decentralized case. The main difference between them is the (non) existence of redistribution rule. In centralized fiscal system, CG makes its decisions according to the total level of tax revenue; however, LG in decentralized case uses a portion of total tax revenue, which is decided by the redistribution rule.

Hence, the balanced budget constraint for CG will be as follows:

$$
G_{t}+R_{t}=A \tau_{t} K_{t}
$$

whereas the lifetime utility form is similar to the equation (1) with a few differences:

$$
\mathrm{U}=\int_{0}^{\infty} \mathrm{e}^{-\rho \mathrm{t}}\left[\ln \mathrm{C}_{\mathrm{t}}+\ln \mathrm{G}_{\mathrm{t}}\right] \mathrm{dt}
$$

In centralized case, there are no different tax rate or interest rate between localities, so law of motion of capital in equation 2 becomes as follows: 


$$
\dot{K}_{t}=\left(1-\tau_{t}\right) i K_{t}-C_{t}
$$

\subsection{Fiscal Centralization and Fiscal Decentralization}

This study does not focus on optimal taxation policy but comparing two different fiscal systems. Ramsey type approach is assumed in the timing of events. So, under full commitment, governments move first and then given the policy decisions, citizens determine their consumption and saving levels. Contrary to the optimal fiscal policy literature of Ramsey problems, this study is not interested in the comparison of primary and dual approaches in Ramsey problem or choosing one to another. This study aims to answer which type of countries can benefit from decentralization or centralization by looking at the parameter values of the model results. Also, how the results differ from the usual findings when a redistribution rule is included into the model.

As a summary, centralized case model is similar to FC model of Chu and Yang (2012). In this case, central government plays the main role in fiscal policy. Local governments have no role in fiscal policy; they only get transfers and distribute them to the citizens in the way of central government's plan. So central government also decides the amounts of transfers to spend and where to spend those transfers.

The timing of the events is as follows:

- CG determines the fiscal policy variables by maximizing the government's utility.

Given these levels, citizens maximize their own lifetime utility.

The most important and distinguishing property of centralized case compared to the decentralized case is the functioning of the LGs. CG sets a fixed tax rate, which eliminates the tax competition for mobile capital between jurisdictions. In addition, it internalizes the spillovers of public goods across jurisdictions. So,

$$
\tau_{t}=\tau_{t}^{*} \text { and } G_{t}=G_{t}^{*}
$$

Adding the symmetricity of two jurisdictions means all the exogenous variables at home be equal to the all the exogenous variables in the foreign jurisdiction. In addition, since no tax competition between two jurisdictions generates the indifference between foreign capital and capital allocated at home, facing mobility cost will not be profitable anymore, i.e. $\theta_{t}=0$. This implies $M\left(\theta_{t}, K_{t}, m\right)=0$

In decentralized case, there is a 3-stage game between LGs, CG, and citizens. LGs are managed by a CG through a redistribution rule and they decide the fiscal policy, whereas CG organizes the transfer amounts.

So, the timing of the events is as follows: 
- $\mathrm{CG}$ announces that it will implement a redistribution rule and only decides the related parameters

- LG determine fiscal variables by maximizing their own lifetime utility.

- Given these levels, citizens maximize their own lifetime utility

\section{Equilibrium Concept and Results}

The equilibrium concept used here is similar to Ortigueira et al. (2012), Krusell and Rios-Rull (1999) and Klein et al. (2008). The information description of how public and private sectors interact defines the equilibrium concept. Markov-perfect Nash equilibrium of this economy by a continuum of households and governments that act sequentially is the main focus of this study. ${ }^{14}$

While governments decide current levels of the tax rate, public good level and rentseeking level, they can see their future choices. Once those choices are known publicly, citizens decide how much to save and consume. So, governments can be regarded as Stackelberg players and therefore can anticipate the effects of current policy on citizen's decisions.

Solution method of this model is backward induction. Because of the complexity of the model, some simplifications are made such as symmetricity of local governments, exogeneity of technology level or degree of politician's selfishness. Wildasin (1988) investigates Nash equilibria for identical jurisdictions under fiscal competition and mobile capital. He shows equal public expenditure and capital levels as well as equal tax rates at Nash equilibrium. The intuition behind this finding is that an increase in tax rate of one locality removes capital out of that jurisdiction since localities are symmetric. Neither jurisdiction has an incentive to change its tax rates, in order not to lose its resources.

Analytical solutions can be found with the help of MATLAB. In order to make policy implications, the effects of some parameters on tax rate, welfare and growth rate are examined. The next two sections present the analytical solutions of the model and examine some important findings of centralized and decentralized cases.

\subsection{Centralized Case}

To derive the solution of the game between CG and citizens, backward induction method is used. The results are similar to Chu and Yang (2012). The following lemma gives the equilibrium outcome where the small letters represent the fractions of capital.

14 In the literature, this type of equilibrium is also called 'government-moves-first Markov-perfect equilibrium' (Klein \& Rios-Rull, 2003; Klein et al. 2008; Ortigueira, 2006). 
Proposition 1: Under centralized case, the symmetric Markov perfect equilibrium outcomes for each point in time $\mathrm{t}$ are ${ }^{15}$

$$
\begin{gathered}
c_{t}^{c}=\rho \\
\tau_{t}^{c}=\frac{\rho}{A(A+1-L)} \\
g_{t}^{c}=\frac{\rho(1-L)}{(A+1-L)} \\
\gamma_{t}^{c}=A-\rho-\frac{\rho}{A+1-L}
\end{gathered}
$$

where $c_{t}$ is the share of capital consumed by the households, $\tau_{t}$ is the tax rate, $g_{t}$ is the share of capital allocated to public goods and $\gamma_{t}$ is the growth rate. The superscript 'c' represents that the finding belongs to the centralized case.

Proof: In the Appendix.

From Proposition 1, citizens consume a constant fraction of capital, which is discount rate only ${ }^{16}$. So, there will be no incentive to change a policy for governments since future policies of governments cannot change the current consumption of citizens. Therefore, we can call those policies as time-consistent policies ${ }^{17}$. Equality of consumption to discount rate supports the idea that degree of willingness to consume today can be measured by discount rate. So, high discount rate means individuals are highly willing to consume more today which concludes with high consumption, and vice versa.

The tax rate decided by the government is also constant through time. As the citizens care more about tomorrow, which implies smaller discount rate $(\rho)$, the tax rate will be lower. The tax rate not only depends on discount rate but also depends on the selfishness of the politician $(L)$. The more selfish the politician is, the higher the tax rate is. It is consistent with the definition of a selfish politician. Selfish politicians tend to increase the tax rate since they want to spend more tax revenue for their own self-interested purposes. Furthermore, the equation of tax rate shows that governments have tendencies to increase tax rate when individuals prefer to consume more today (i.e. higher discount rate) since they want to utilize from higher tax rate as collecting more tax revenue.

15 The detailed version of the solution is in the Appendix.

16 There are similarities between long run steady state of consumption share in neoclassical view and the consumption share in Proposition 1. In the long run steady state, the share of consumption in income is equal to the rate of time preference so equal to the interest rate. However, the reason why people save today is not the interest rate increases, rather interest rates must be positive in order to convince impatient citizens save for tomorrow. This solution is also the same with the finding in Chu and Yang (2012). 
The share of capital that is used for public good ${ }^{18}$ is constant over time and depends on not only the selfishness of the politician $(L)$ but also the discount rate with technology level. When the selfishness of the politician increases, more tax revenue will be spent for the politician's self-interested purposes, so that the share for public good level will be smaller since the tax revenue is used either for public good provision or politician's self-interests.

The growth rate of capital is also constant over time. Higher technology level implies higher growth rate whereas higher discount rate causes smaller growth rate. Impatient citizens have a tendency to consume more today, which implies a higher discount rate. This impatience causes less saving which decreases the growth rate. In addition to technology and discount rate, selfishness of the politician also affects the growth rate of capital. This parameter $(L)$ does not depend on time but depends on the politician that was elected. Higher $L$ means politician uses the resources for his own interests instead of public good provision, which causes smaller growth rate.

Figure 1 shows the behavior of the relationships between tax rate and discount rate (Panel A) and growth rate and discount rate (Panel B) for the corner values of selfishness degree $^{19}$. The red lines belong to the case of fully selfish government $(L=1)$ and blue lines belong to the case of fully benevolent government $(L=0)$. If a fully benevolent government is switched to a fully selfish government then the slope of the graph increases significantly in absolute terms. Because fully benevolent government uses its resources more to the public needs which implies higher growth rate with lower tax rate; whereas fully selfish government uses resources for itself and so waste the resources which entails smaller growth rate with higher tax rate.

18 Share of capital that is spent for public good: $\frac{G_{t}}{K_{t}}=g_{t}^{c}$.

$19 L \in[0,1]$ so the corner levels are 0 and 1 . When $L=0$, the government is fully benevolent, i.e. it only cares about the citizens' utility; however when $L=1$, the government is fully selfish, i.e. it does not care about the citizens' utility but his utility only. 


\section{Figure: 1}

(A) Tax Rate and Discount Rate

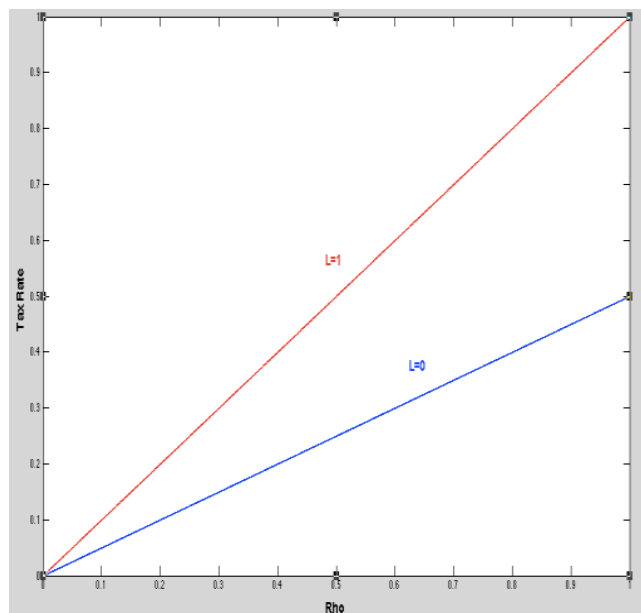

Rhe

(B) Growth Rate and Discount Rate

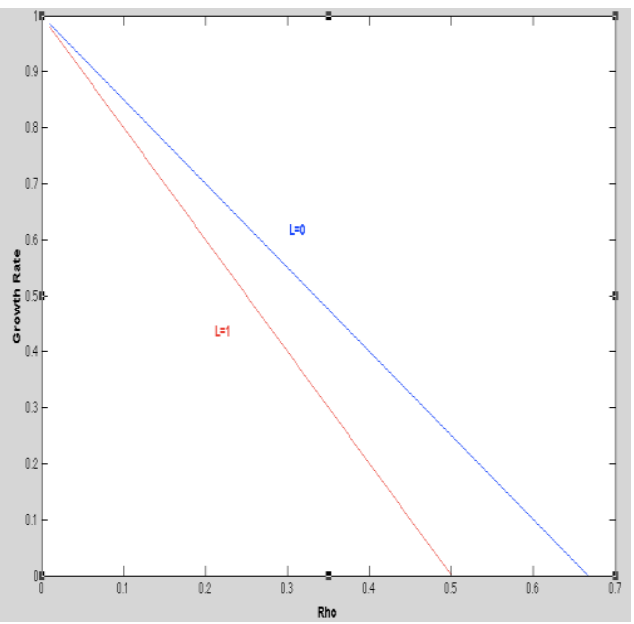

Source: The Author's calculations by using the findings of proposition 1 and parameter values in Table 1.

* Rho represents the discount rate $(\rho)$

\subsection{Decentralized Case}

Through backward induction, the following lemma gives the equilibrium outcome where the small letters represent the fractions of capital.

Proposition 2: Under decentralized case, the symmetric Markov perfect equilibrium outcomes for each point in time $t$ are $^{20}$.

$$
\begin{gathered}
c_{t}^{d}=\rho \\
\tau_{t}^{d}=f(m, L, A, \rho, \varphi, p, \tilde{t}, \tilde{y}) \\
\gamma_{t}^{d}=A\left(1-\tau_{t}^{d}\right)-\rho \\
g_{t}^{d}=\frac{p \rho(1-L)(1-s)}{A[1+(1-L)(1-s)]\left[A(1+m)\left(\tau_{t}^{d}-1\right)-1\right]}
\end{gathered}
$$

where $c_{t}$ is the share of capital consumed by the households, $\tau_{t}$ is the tax rate, $g_{t}$ is the share of capital allocated to public goods, $\gamma_{t}$ is the growth rate, $\tilde{t}$ is the targeted tax revenue level 
divided by capital and $\tilde{y}$ is the targeted income level divided by capital. The superscript 'd, represents that the finding belongs to the decentralized case.

Proof: In the Appendix.

As in the centralized case, citizens consume a constant fraction of capital. Despite the equality in the consumption level since the utility form of the citizens is different, the welfare level of the citizens for these two cases ${ }^{21}$ will be different. The constant fraction of capital shows the time consistency of the variable. Even LG decides to change its policy; the consumption level of the citizen will not be changed, so LG has no incentive to change its policy.

All the variables depend on time-independent fraction of capital. However, it is not easy to interpret the findings so comparative statics analysis is performed and presented as lemmas below.

Lemma 1: As the selfishness of the politician increases or the degree of spillovers decreases (i.e. utility taken from the foreign public good is lower), LG increases the tax rate of its own jurisdiction.

Proof: First order derivative of the tax rate with respect to $L$ and $s$ are positive and negative respectively.

$$
\frac{\partial \tau^{d}}{\partial L}=\frac{-p \rho}{(L+s-L s-2)}\left[\frac{1}{\left(h_{1}\right)^{1 / 2}}\right]>0 \text { since } L \epsilon[0,1], s \in[0,0.5]
$$

where $h_{1}$ is a function of $m, L, A, \rho, \varphi, p, \tilde{t}, \tilde{y}$

$$
\frac{\partial \tau^{d}}{\partial s}=\frac{p \rho(L-1)^{2}}{(L+s-L s-2)}\left[\frac{1}{A\left(h_{1}\right)^{\frac{1}{2}}}\right]<0 \text { since } L \epsilon[0,1], s \in[0,0.5]
$$

where $h_{1}$ is a function of $m, L, A, \rho, \varphi, p, \tilde{t}, \tilde{y}$

Higher L means politician wants to spend more tax revenue for his interests while caring less about the welfare of the citizens, so that the politician sees no harm increasing the tax rate. For the latter one, firstly LGs have a tendency to increase tax rate because of higher tax revenue and spending power. However, if tax rate is high enough, that locality may face two obstacles: losing capital to other locality, which causes reductions in tax revenue and losing the next election because utility of the citizens will be harmed from high tax rates. Smaller degree of spillovers $(s)$ indicates low levels of utility taken from the foreign 
jurisdiction's public good level, which points out that there is still room for an increase in tax rate and still locality will not lose capital to other jurisdiction.

Lemma 2: The selfishness of the politician harms the growth rate since as the selfishness of the politician increases, LGs increase the tax rate. In addition, when the degree of positive spillovers increases, the growth rate of the economy increases.

Proof: The sign of first-order derivative of growth rate with respect to $L$ is positive whereas first-order derivative of growth rate with respect to $s$ is negative without any condition.

$$
\begin{aligned}
& \frac{\partial \gamma^{d}}{\partial L}=\frac{A p \rho}{(L+s-L s-2)}\left[\frac{1}{\left(h_{1}\right)^{1 / 2}}\right]<0 \text { since } L \epsilon[0,1], s \in[0,0.5] \\
& \frac{\partial \gamma^{d}}{\partial s}=\frac{-A p \rho(L-1)^{2}}{(L+s-L s-2)}\left[\frac{1}{A\left(h_{1}\right)^{\frac{1}{2}}}\right]>0 \text { since } L \epsilon[0,1], s \in[0,0.5]
\end{aligned}
$$

Politicians govern localities, and fiscal policies will be affected from their decisions. Since selfish politicians regard less of citizens, they will increase tax rate and spend tax revenue for their own interests, which adversely affects the growth rate. This finding combining with the lemma 1 composes the second result, positive relation between the degree of spillovers and the growth rate.

Lemma 3: The capital mobility affects the tax rate adversely, in other words as capital mobility increases, tax rate decreases.

Proof: First order derivative of the tax rate with respect to $m$ is positive.

$$
\frac{\partial \tau^{d}}{\partial m}=-\left(h_{2}\right)^{\frac{1}{2}}(m+1)^{2}<0
$$

where $h_{2}$ is a function of $m, L, A, \rho, \varphi, p, \tilde{t}, \tilde{y}$

Capital can move less costly in case of higher capital mobility compared to lower case. In this study, only tax revenue source for LGs comes with the capital income taxation; hence in order not to lose more capital, LGs decrease their tax rate when capital mobility increases.

Lemma 4: As the targeted tax revenue and targeted income level increase, the growth rate decreases and increases respectively.

Proof: It is the first order derivative of the growth rate with respect to $\tilde{t}$ and $\tilde{y}$.

$$
\frac{\partial \gamma^{d}}{\partial \tilde{t}}=-1<0 \text { and } \frac{\partial \gamma^{d}}{\partial \tilde{y}}=\frac{\varphi}{p}>0
$$


When CG increases the targeted tax revenue, LGs have tendency to increase the tax rate, which affects the growth adversely. The intuition for the latter one is that if the CG increases the targeted income level, transfers, distributed to LGs by CG, increase due to the equity part in redistribution rule. This upturn provides spending more and triggers the growth rate of the economy.

\subsection{Comparison Between FD and FC}

This section makes a comparison between the centralized and the decentralized cases in terms of fiscal policy variables, which are analytically solved. Due to the complexity of the solutions, some comparisons cannot be concluded in which case simulation analysis is run by setting some ranges or imposing corner values for the related parameters ${ }^{22}$. Table 1 presents detailed values for the parameters.

Table: 1

Parameter Values

\begin{tabular}{|c|l|c|c|l|c|}
\hline & Parameter Name & Value & & Parameter Name & Value \\
\hline$\rho$ & Discount Rate & 0.01 & $s$ & Positive Spillovers & {$[0,1]$} \\
\hline$A$ & Level of Technology & 0.4 & $m$ & Capital Mobility & {$[0, \infty]$} \\
\hline$K_{0}^{a}$ & Initial Capital & 1 & $\tilde{t}$ & Targeted Rate & {$[0,0.5]$} \\
\hline$L$ & Selfishness & {$[0,1]$} & $\tilde{y}$ & Targeted Income & 0.3714 \\
\hline
\end{tabular}

In the literature, a discount rate of discrete-time models is assumed to be $0.99^{23}$. This value corresponds to 0.01 in continuous time models. According to the US data, capitalincome ratio is approximately $2.5^{24}$. By using this capital-income ratio, the level of technology is calculated as 0.4 since AK-type endogenous growth model is used in this study. The initial capital level is assumed to be 1 due to the simplicity purposes. Other possible values for initial capital are tested, however, this does not change the results of comparisons. In addition to these parameter values, there are some parameters, which are neither widely used in the literature nor measured in real-time situations such as selfishness of the politicians, degree of positive spillovers, etc. This problem is overcome by applying normalized ranges for these parameters. These ranges with intuitions are already explained in the model part in detail.

Proposition 3: Citizens consume the same and constant fraction of capital in both decentralized and centralized cases.

$$
c_{t}^{d}=\rho=c_{t}^{c}
$$

22 The MATLAB codes can be provided upon request.

23 Otrok (2001), Jones (2002).

24 This ratio is calculated and preferred in the studies investigating Kaldor's stylized facts in the literature. 
This finding can be easily identified from the propositions 1 and 2 .

Result 1: When there are spillovers among LGs $(s \neq 0)$ and the governments are not fully selfish $(L \neq 1)$, the welfare in FD is higher than the one in FC model despite the tax rate of FD is also higher than the tax rate of FC.

This result may seem contradictory to the most of the findings in the literature, which claims in the existence of spillovers, welfare level of FC is higher than the one of FD, however in Decentralization Theorem or the studies in the literature, there is no redistribution mechanism that may discipline the local governments. This result shows the usefulness of FD with redistribution mechanism by not only providing fiscal discipline but also increasing the welfare. In the redistribution rule of FD case, a target for tax revenue is set exogenously in efficiency property, however, in FC, the CG is free to choose any tax rate since they are not tied to any target which leads to higher tax rate in FD than in FC. At first glance, low levels of tax rate mean an improvement for citizens due to the higher level of disposable income, but it also implies low levels of tax revenue, and hence low levels of public good provision. In the model, the objective function of a citizen is not only composed of consumption level but also public good level at home jurisdiction and neighbor jurisdiction. Consumption level may increase, because of the increase in disposable income, but public good provision levels lessen which causes lower levels of utility. In other words, the increase in consumption level is dominated by the decrease in public good level at home and neighbor jurisdictions. Hence, in presence of spillovers, public good levels matter more than consumption levels for citizens.

Result 2: When spillovers are not allowed $(\mathrm{s}=0)$ and the governments are not fully selfish $(L \neq 1)$, capital mobility plays a crucial role in welfare comparison between FD with redistribution rule and FC. In case of low capital mobility, welfare in FD model is higher than the one in FC, whereas, in case of high capital mobility, welfare in FC model is higher than the one in FD.

This result is consistent with the finding of Chu and Yang (2012), which shows the importance of capital mobility when there are no spillovers. In the case of low capital mobility, tax competition may not be so active which may result with higher tax rate. When tax competition is high enough, local governments choose low tax rate which results with under provision of public goods so lower levels of welfare. This result is similar with the fundamental static result in the tax competition literature ${ }^{25}$, which tells that tax competition for mobile capital is harmful since it tends to produce a low tax rate and result in an under provision of public goods. 
Result 3: The growth rate of the economy in the case of FD with redistribution rule is less than the one in case of FC when spillovers are allowed $(s \neq 0)$.

This result is an unexpected result since in the literature there are empirical studies that show both a positive relation between growth rate and FD measures ${ }^{26}$ and uncorrelated relation between them ${ }^{27}$. In this study, the difference comes with the redistribution rule in which there is a targeted tax rate level that makes the LGs choose around this level. In FC case, there is no such a target level; this causes to reach a higher growth rate. In other words, due to fiscal discipline with a redistribution rule, even in case of tax competition, local governments cannot choose a tax rate whatever level they want, for instance, a low tax rate. Hence, the growth rate of FC model is higher than the growth rate of FD model.

Result 4: For low levels of selfishness of the politician, as the degree of positive spillovers increases, tax revenue share for public good provision also increases. On the oher hand, for high levels of selfishness of the politicians, a higher degree of positive spillovers lessens the tax revenue share for public good provision.

The intuition behind this result is as follows: Assume the politician has a low selfishness parameter (low L) then when the degree of positive spillovers increases (i.e. the utility taken from the foreign public good increases), the LG spends more to public good provision not to lose the capital of its citizens (i.e. tax revenue share for public good provision increases). However, there is a threshold level that the LG can do to retain the capital of its citizens, which depends on selfishness parameter. For higher L, LG does not try to keep its citizens so decrease its public good spending. Even increasing the degree of positive spillovers does not change this decrease. This result seems so obvious from the construction of the model; however, the key point is that the degree of spillovers and degree of selfishness parameter change simultaneously (i.e. mathematically speaking, it is a second derivative) and this is not so trivial from the model.

\section{Conclusion}

In this paper, the effects of FD with a redistribution rule and FC are investigated and compared. The main contribution of this paper to the literature is introducing a linear redistribution rule to the FD case in order to investigate whether this mechanism affect the usual findings in the literature. The necessity of a redistribution rule is widely discussed and accepted in the literature under the condition that it should have some properties such as equity, local tax effort, transparency, simplicity, etc. In addition, the theoretical studies of FD and FC comparisons do not use such a redistribution rule in their models; however,

26 Lin and Liu (2000), Akai and Sakata (2002), Iimi (2005).

27 Davoodi and Zou (1998), Woller and Philips (1998), Thornton (2007). 
Wilson (1999) states that if tax competition is included in a theoretical model, an intergovernmental mechanism should be included in order to obtain accurate results.

The difference between FD and FC arises from the existence of coordination in fiscal policy between jurisdictions. In the decentralized set-up, firstly CG decides transfer amounts by choosing related parameters, and given transfers, LGs determine fiscal policy. Then given their decisions, citizens choose how much to consume and invest. On the other hand, in the centralized set-up, CG plays the key role in fiscal policy and LGs have no active role in choosing tax rate or public good level. Given fiscal policy, citizens maximize their lifetime utility subject to budget constraint.

Throughout this study, some assumptions, such as symmetric jurisdictions, only capital taxation, and capital mobility, are made in order to reduce the complexity of the model while not losing the focus of the study.

The models can be solved analytically, however, comparisons of FD with redistribution rule versus FC cannot be interpreted due to the complexity of the results. Thus, simulation analysis is implemented. Both in the cases of decentralized and centralized, timeconsistent policies are observed. Simulation analysis shows both degrees of spillovers and capital mobility plays a role in comparing two cases in terms of welfare and growth. When there are spillovers among LGs, the welfare in FD model is higher than the one in FC, which is a contradicting result with Oates' Decentralization Theorem. This may be due to imposing intergovernmental transfer mechanism in decentralized case. When spillovers are not allowed, capital mobility affects the dominant case in welfare. For low mobility, FD provides higher welfare than FC. This finding shows the decisive role of tax competition since tax competition is run through the capital.

Another observation is that FD provides fiscal discipline, which is stated as one of the main concerns about FD. Fiscal discipline is maintained by the redistribution rule, where there is a targeted tax revenue level that LG should reach. If LG cannot reach this level, the $\mathrm{CG}$ punishes the it by decreasing the transfers. So, we can also see the effectiveness of this punishment mechanism since we observe that tax revenue levels and tax rates will be close to these targeted levels. This observation can be driven from the interpretations of the lemmas and the simulations results as a whole.

\section{References}

Akai, N. \& M. Sakata (2002), "Fiscal decentralization contributes to economic growth: evidence from state- level cross-section data for the United States", Journal of Urban Economics, 52, 93-108.

Akin, Z. \& Z.B. Bulut-Cevik \& B. Neyapti (2016), "Does fiscal decentralization promote fiscal discipline?", Emerging Markets, Finance and Trade, 52(3), 690-705.

Besley, T. \& S. Coate (2003), “Centralised versus decentralised provision of local public goods: a political economy approach", Journal of Public Economics, 87(12), 2611-2637.

Bradford, D.F. \& W.E. Oates (1971), "The analysis of revenue sharing in a new approach to collective fiscal decisions", The Quarterly Journal of Economics, 85(3), 416-439. 
Brennan, G. \& J.M. Buchanan (1980), The Power to Tax: Analytical Foundations of a Fiscal Constitution, Cambridge University Press, New York.

Brueckner, J.K. (2003), "Strategic interaction among governments: An overview of empirical studies", International Regional Science Review, 26(2), 175-188.

Chu, A.C. \& C.C. Yang (2012), "Fiscal centralization versus decentralization: Growth and welfare effects of spillovers, Leviathan taxation, and capital mobility", Journal of Urban Economics, 71, 177-188.

Davoodi, H. \& H. Zou (1998), "Fiscal decentralization and economic growth: A Cross- Country Study", Journal of Urban Economics, 43, 244-257.

Deveraux, M.P. \& B. Lockwood \& M. Redeona (2008), "Do countries compete over corporate tax rates?", Journal of Public Economics, 92(5), 1210-1235.

Edwards, J. \& M. Keen (1996), "Tax competition and Leviathan”, European Economic Review, 40, 113-134.

Epple, D. \& T. Nechyba (2004), "Fiscal decentralization”, in: J.V. Henderson \& J.F. Thisse (eds.) Handbook of Regional and Urban Economics, Volume: 4, Chapter: 55.

Eyraud, L. \& L. Lusinyan (2011), "Decentralizing Spending More than Revenue: Does It Hurt Fiscal Performance?", IMF Working Paper, WP/11/226.

Haufler, A. (2001), Taxation in a global economy, Cambridge Books, Cambridge University Press.

Iimi, A. (2005), "Decentralization and economic growth revisited: an empirical note", Journal of Urban Economics, 57, 449-461.

Jones, J.B. (2002), "Has fiscal policy helped stabilized the postwar U.S. economy?", Journal of Monetary Policy, 49, 709-746

Klein, P. \& J.V. Rios-Rull (2003), "Time-Consistent optimal fiscal policy”, International Economic Review, 44(4), 1207-1405.

Klein, P. \& P. Krusell \& J.V. Rios-Rull (2008), “Time-Consistent public policy”, Review of Economic Studies, 75(3), 789-808.

Krusell, P. \& J.V. Rios-Rull (1999), "On the size of US government: Political economy in the neoclassical growth model”, The American Economic Review, 89(5), 1156-1181.

Lejour, A. \& H.A. Verbon (1997), "Tax competition and redistribution in a two-country endogenousgrowth model”, International Tax and Public Finance, 4, 485-497.

Lin, J.Y. \& Z. Liu (2000), "Fiscal decentralization and economic growth in China", Economic Development and Cultural Change, 49, 1-21.

Lockwood, B. (2006), "Fiscal decentralization: a political economy perspective", in: E. Ahmad \& G. Brosio (eds.), Handbook of fiscal federalism, Edward Elgar.

Ma, J. (1997), "Intergovernmental Fiscal Transfers in Nine Countries", prepared for Macroeconomic Management and Policy Division, Economic Development Institute, The World Bank.

Oates, W.E. (1972), Fiscal federalism, Harcourt-Brace, New York.

Oates, W.E. (1999), “An Essay on Fiscal Federalism”, Journal of Economic Literature, 37(3), 11201149.

Ortigueira, S. \& J. Pereira \& P. Pichler (2012), "Markov-perfect optimal fiscal policy: The case of unbalanced budgets", Universidad Carlos III de Madrid Working Paper, Economic Series, 12-30. 
Ortigueira, S. (2006), “Markov-perfect optimal taxation”, Review of Economic Dynamics, 9(1), 153178.

Otrok, C. (2001), "On measuring the welfare cost of business cycles", Journal of Monetary Policy, 47, 61-92.

Persson, T. \& G. Tabellini (1992), "The politics of 1992: fiscal policy and European integration”, Review of Economic Studies, 59, 689-701.

Rauscher, M. (1998), "Leviathan and competition among jurisdictions: the case of benefit taxation", Journal of Urban Economics, 44, 59-67.

Rohac, D. (2006), "Evidence and myths about tax competition", New Perspectives on Political Economy, 2(2), 86-115.

Shah, A. (1995), "Theory and Practice of Intergovernmental Transfers", Reforming China's Public Finances, 215-234.

Thornton, J. (2007), "Fiscal decentralization and economic growth reconsidered", Journal of Urban Economics, 61(1), 64-70.

Tiebout, C.M. (1956), “A Pure Theory of Local Expenditures”, The Journal of Political Economy, 64(5), 416-424.

Wellisch, D. (2000), Theory of Public Finance in a Federal State, Cambridge University Press, Cambridge.

Wildasin, D.E. (1988), "Nash Equilibria in Models of Fiscal Competition”, Journal of Public Economics, 35, 229-240.

Wilson, J.D. (1986), “A theory of interregional tax competition”, Journal of Urban Economics, 19, 296-315.

Wilson, J.D. (1999), “Theories of Tax Competition”, National Tax Journal, 52(2), 269-304.

Winner, H. (2005), "Has tax competition emerged in OECD Countries? Evidence form Panel Data", International Tax and Public Finance, 12(5), 667-687.

Woller, G.M. \& K. Philips (1998), "Fiscal decentralization and LDC growth: an empirical investigation", Journal of Development Studies, 34, 138-148.

Xie, D. (1997), "On time inconsistency: A technical issue in Stackelberg differential games”, Journal of Economic Theory, 76(2), 412-430.

Zodrow, G.R. \& P. Mieszkowki (1986), "Pigou, Tiebout, Property Taxation and the Underprovision of Local Public Goods", Journal of Urban Economics, 19, 356-370.

Zodrow, G.R. (2003), "Tax Competition and Tax Coordination in the European Union", International Tax and Public Finance, 10, 651-671. 


\section{APPENDIX}

\section{Centralized Case:}

Citizen's Problem:

$$
U=\max _{\left\{C_{t}, K_{t}\right\}} \int_{0}^{\infty} e^{-\rho t}\left[\ln C_{t}+\ln G_{t}\right] d t
$$

subject to

$$
\dot{K}_{t}=\left[A-c_{t}-\mathrm{i} \tau_{t}\right] K_{t}
$$

Given $G_{t}, \tau_{t}$

The current value hamiltonian becomes ${ }^{28}$

$$
\mathcal{H}=\ln c_{t} K_{t}+\ln g_{t} K_{t}+\mu_{t}\left(A-c_{t}-\mathrm{i} \tau_{t}\right) K_{t}
$$

The first order conditions with respect to $c_{t}, K_{t}, \mu_{t}$ are as follows:

$$
\begin{gathered}
\frac{\partial \mathcal{H}_{t}}{\partial c_{t}}=\frac{1}{c_{t} K_{t}} K_{t}-\mu_{t} K_{t} \\
\frac{\partial \mathcal{H}_{t}}{\partial K_{t}}=\frac{1}{c_{t} K_{t}} c_{t}+\mu_{t}\left(A-c_{t}-\tau_{t}\right)=\mu_{t} \rho-\dot{\mu}_{t} \\
\frac{\partial \mathcal{H}_{t}}{\partial \mu_{t}}=K_{t}\left(A-c_{t}-\tau_{t}\right)=\dot{K}_{t}
\end{gathered}
$$

The first order conditions, transversality condition $\left(\lim _{t \rightarrow \infty} e^{-\rho t} \mu_{t} K_{t}=0\right)$ and the firm problem's result, $(i=A)$, give the following result

$$
K_{t} \mu_{t} \rho-1=\mu_{t} \dot{K}_{t}+K_{t} \dot{\mu}_{t}
$$

Integrating this result with respect to time shows that consumption is a constant fraction of capital level

$$
C_{t}=\rho K_{t}
$$

28 Denote $g_{t}=G_{t} / K_{t}$ as the share of capital allocated to public goods and $c_{t}={ }_{t} / K_{t}$ as the share of capital consumed by the households. (Chu \& Yang, 2012). 
Since $\mu_{0}=\left(\rho K_{0}\right)^{-1}$ is predetermined since $\mu_{0}$ cannot be controlled by the government. $K_{0}$ is given, $\rho$ is a parameter and so $c_{t}$ is independent from the government policy which means it is time consistent.

The growth rate

$$
\gamma_{t}=A-\rho-A \tau_{t}
$$

Central Government's Problem:

$$
V=\max _{G_{t}, \tau_{t}, R_{t}, K_{t}}(1-L) U+L \int_{0}^{\infty} e^{-\rho t}\left[\ln R_{t}\right] d t
$$

subject to

$$
\begin{gathered}
G_{t}+R_{t}=N_{t}=A \tau_{t} K_{t}=A\left(g_{t}+r_{t}\right) K_{t} \\
\dot{K}_{t}=\left[A-\rho-i \tau_{t}\right] K_{t}
\end{gathered}
$$

where $U=\ln C_{t}+\ln G_{t}$

The current value Hamiltonian becomes

$$
\mathcal{H}=(1-L)\left[\ln c_{t} K_{t}+\ln g_{t} K_{t}\right]+L\left[\ln r_{t} K_{t}\right]+\hat{\mu}_{t} K_{t}\left(A-\rho-i \tau_{t}\right)+\lambda_{t} K_{t}\left(\tau_{t}-g_{t}-r_{t}\right)
$$

First order conditions with respect to $\tau_{t}, K_{t}, g_{t}, r_{t}, \hat{\mu}_{t}, \lambda_{t}$ are as follows respectively:

$$
\begin{gathered}
\frac{\partial \mathcal{H}_{t}}{\partial \tau_{t}}=-\hat{\mu}_{t} K_{t}+\lambda_{\mathrm{t}} \mathrm{K}_{\mathrm{t}} \\
\frac{\partial \mathcal{H}_{t}}{\partial K_{t}}=\frac{1-L}{c_{\mathrm{t}} \mathrm{K}_{\mathrm{t}}} c_{\mathrm{t}}+\frac{1-L}{\mathrm{~g}_{\mathrm{t}} \mathrm{K}_{\mathrm{t}}} \mathrm{g}_{\mathrm{t}}+\frac{L}{\mathrm{r}_{\mathrm{t}} \mathrm{K}_{\mathrm{t}}} \mathrm{r}_{\mathrm{t}}+\hat{\mu}_{\mathrm{t}}\left(\mathrm{A}-\rho-\tau_{\mathrm{t}}\right)+\lambda_{\mathrm{t}}\left(\tau_{\mathrm{t}}-\mathrm{g}_{\mathrm{t}}-\mathrm{r}_{\mathrm{t}}\right)=\hat{\mu}_{\mathrm{t}} \rho-\hat{\mu}_{\mathrm{t}} \\
\frac{\partial \mathcal{H}_{t}}{\partial g_{t}}=\frac{1-L}{\mathrm{~g}_{\mathrm{t}} \mathrm{K}_{\mathrm{t}}} \mathrm{K}_{\mathrm{t}}-\lambda_{\mathrm{t}} \mathrm{K}_{\mathrm{t}}=0 \\
\frac{\partial \mathcal{H}_{t}}{\partial r_{t}}=\frac{L}{\mathrm{r}_{\mathrm{t}} \mathrm{K}_{\mathrm{t}}} \mathrm{K}_{\mathrm{t}}-\lambda_{\mathrm{t}} \mathrm{K}_{\mathrm{t}}=0 \\
\frac{\partial \mathcal{H}_{t}}{\partial \hat{\mu}_{t}}=\mathrm{K}_{\mathrm{t}}\left(\mathrm{A}-\rho-\tau_{\mathrm{t}}\right)=\dot{\mathrm{K}}_{\mathrm{t}} \\
\frac{\partial \mathcal{H}_{t}}{\partial \lambda_{t}}=\mathrm{K}_{\mathrm{t}}\left(\tau_{\mathrm{t}}-\mathrm{g}_{\mathrm{t}}-\mathrm{r}_{\mathrm{t}}\right)=0
\end{gathered}
$$

The first order conditions, transversality condition $\left(\lim _{t \rightarrow \infty} e^{-\rho t} \hat{\mu}_{t} K_{t}=0\right)$ and the firm problem's result, $(r=A)$, give the following result

$$
\hat{\mu}_{\mathrm{t}} \dot{\mathrm{K}}_{\mathrm{t}}-\dot{\hat{\mu}}_{\mathrm{t}} \mathrm{K}_{\mathrm{t}}=\hat{\mu}_{\mathrm{t}} \mathrm{K}_{\mathrm{t}} \rho-(2-\mathrm{L})
$$


Integrating with respect to time, then $\hat{\mu}_{\mathrm{t}} \mathrm{K}_{\mathrm{t}}=(2-L) / \rho$. Substituting this into the first order conditions, choice variables will be as follows:

$$
\begin{gathered}
\tau_{t}=\frac{\rho}{A(A+1-L)} \\
g_{t}=\frac{\rho(1-L)}{(A+1-L)} \\
\gamma_{t}=A-\rho-\frac{\rho}{A+1-L}
\end{gathered}
$$

\section{Decentralized Case:}

Citizen's Problem:

$$
U=\max _{\left\{C_{t}, K_{t}, \theta_{t}\right\}} \int_{0}^{\infty} e^{-\rho t}\left[\ln C_{t}+(1-\mathrm{s}) \ln G_{t}+s \ln G_{t}^{*}\right] d t
$$

subject to

$$
\dot{K}_{t}=\left(1-\tau_{t}\right) i D_{t}+\left(1-\tau_{t}^{*}\right) i^{*} F_{t}-C_{t}-K_{t}\left(\theta_{t}\right)^{2} / m
$$

Given $G_{t}, G_{t}^{*}, \tau_{t}, \tau_{t}^{*}$

The current value hamiltonian becomes

$$
\mathcal{H}=\begin{gathered}
\ln c_{t} K_{t}+(1-\mathrm{s}) \ln g_{t} K_{t}+s \ln g_{t}{ }^{*} K_{t}{ }^{*}+ \\
\mu_{t}\left(A-c_{t}-\left(1-\theta_{t}\right) i \tau_{t}-\theta_{t} i^{*} \tau_{t}^{*}-\left(\theta_{t}\right)^{2} / m\right) K_{t}
\end{gathered}
$$

The first order conditions with respect to $c_{t}, K_{t}, \theta_{t}, \mu_{t}$ are as follows:

$$
\begin{gathered}
\frac{\partial \mathcal{H}_{t}}{\partial c_{t}}=\frac{1}{c_{t} K_{t}} K_{t}-\mu_{t} K_{t}=0 \\
\frac{\partial \mathcal{H}_{t}}{\partial K_{t}}=\frac{1}{c_{t} K_{t}} c_{t}+\frac{1}{g_{t} K_{t}} g_{t}+\mu_{t}\left(A-c_{t}-\left(1-\theta_{t}\right) i \tau_{t}-\theta_{t} i^{*} \tau_{t}^{*}-\left(\theta_{t}\right)^{2} / m\right)=\mu_{t} \rho-\dot{\mu}_{t} \\
\frac{\partial \mathcal{H}_{t}}{\partial \theta_{t}}=\mu_{t}\left(i \tau_{t}-i^{*} \tau_{t}^{*}-2^{\theta_{t} / m}\right)=0 \\
\frac{\partial \mathcal{H}_{t}}{\partial \mu_{t}}=K_{t}\left(A-c_{t}-\left(1-\theta_{t}\right) i \tau_{t}-\theta_{t} i^{*} \tau_{t}^{*}-\left(\theta_{t}\right)^{2} / m\right)=\dot{K}_{t}
\end{gathered}
$$

The first order conditions, transversality condition $\left(\lim _{t \rightarrow \infty} e^{-\rho t} \mu_{t} K_{t}=0\right)$ and the firm problem's finding, $\left(i=A=i^{*}\right)$, give the following results 


$$
\begin{gathered}
\theta_{t}=\frac{m}{2}\left[\tau_{t}-\tau_{t}^{*}\right] \\
C_{t}=\rho K_{t} \\
\gamma_{t}=A\left(1-\tau_{t}\right)-\rho
\end{gathered}
$$

Local Government's Problem:

$$
V=\max _{G_{t}, \tau_{t}, R_{t}}(1-L) U+L \int_{0}^{\infty} e^{-\rho t}\left[\ln R_{t}\right] d t
$$

subject to

$$
\begin{gathered}
G_{t}+R_{t}=\mathrm{p}\left[\tau_{\mathrm{t}} \mathrm{K}_{\mathrm{t}}-\widetilde{\mathrm{T}}_{\mathrm{t}}\right]+\varphi\left[\breve{\mathrm{Y}}_{\mathrm{t}}-\mathrm{AK}_{\mathrm{t}}\right] \\
\dot{K}_{t}=\left(1-\tau_{t}\right) i D_{t}+\left(1-\tau_{t}^{*}\right) i^{*} F_{t}-C_{t}-K_{t}\left(\theta_{t}\right)^{2} / m \\
\theta_{t} \in[0,1], K_{t}>0, C_{t}>0
\end{gathered}
$$

where $U=\ln C_{t}+(1-s) \ln G_{t}+s \ln G_{t}{ }^{*}$

The current value hamiltonian becomes ${ }^{29}$

$$
\begin{aligned}
\mathcal{H}=(1-L)\left[\ln \mathrm{c}_{\mathrm{t}}\right. & \left.\mathrm{K}_{\mathrm{t}}+(1-\mathrm{s}) \ln \mathrm{g}_{\mathrm{t}} \mathrm{K}_{\mathrm{t}}+s \ln g_{t}^{*} K_{t}^{*}\right]+\mathrm{L}\left[\ln \mathrm{r}_{\mathrm{t}} \mathrm{K}_{\mathrm{t}}\right]+\hat{\mu}_{\mathrm{t}} \mathrm{K}_{\mathrm{t}}(A-\rho \\
& \left.-\left(1-\theta_{t}\right) i \tau_{t}-\theta_{t} i^{*} \tau_{t}^{*}-\left(\theta_{t}\right)^{2} / m\right)+\lambda_{\mathrm{t}} \mathrm{K}_{\mathrm{t}}\left(\mathrm{p}\left(\tau_{t}-\widetilde{t_{t}}\right)+\varphi\left(\widetilde{y_{t}}-A\right)\right. \\
& \left.-\mathrm{g}_{\mathrm{t}}-\mathrm{r}_{\mathrm{t}}\right)
\end{aligned}
$$

First order conditions with respect to $\tau_{t}, K_{t}, g_{t}, r_{t}, \hat{\mu}_{t}, \lambda_{t}$ are as follows respectively:

$$
\begin{gathered}
\frac{\partial \mathcal{H}_{t}}{\partial \tau_{t}}=-\hat{\mu}_{t} K_{t} i\left(1-\theta_{t}\right)+\mathrm{p} \lambda_{\mathrm{t}} \mathrm{K}_{\mathrm{t}}+\hat{\mu}_{t} K_{t} m A / 2\left[i \tau_{t}-i^{*} \tau_{t}^{*}-2 \theta_{t} / m\right] \\
\frac{\partial \mathcal{H}_{t}}{\partial K_{t}}=\frac{1-L}{\mathrm{c}_{\mathrm{t}} \mathrm{K}_{\mathrm{t}}} \mathrm{c}_{\mathrm{t}}+\frac{1-L}{\mathrm{~g}_{\mathrm{t}} \mathrm{K}_{\mathrm{t}}}(1-\mathrm{s}) \mathrm{g}_{\mathrm{t}}+\frac{L}{\mathrm{r}_{\mathrm{t}} \mathrm{K}_{\mathrm{t}}} \mathrm{r}_{\mathrm{t}}+\hat{\mu}_{\mathrm{t}}\left(\mathrm{A}-\rho-\left(1-\theta_{t}\right) i \tau_{t}-\theta_{t} i^{*} \tau_{t}^{*}-\left(\theta_{t}\right)^{2} / m\right) \\
+\lambda_{\mathrm{t}}\left(\mathrm{p}\left(\tau_{t}-\widetilde{t_{t}}\right)+\varphi\left(\tilde{y_{t}}-A\right)-\mathrm{g}_{\mathrm{t}}-\mathrm{r}_{\mathrm{t}}\right)=\hat{\mu}_{\mathrm{t}} \rho-\hat{\hat{\mu}}_{\mathrm{t}} \\
\frac{\partial \mathcal{H}_{t}}{\partial g_{t}}=\frac{1-L}{\mathrm{~g}_{\mathrm{t}} \mathrm{K}_{\mathrm{t}}}(1-\mathrm{s}) \mathrm{K}_{\mathrm{t}}-\lambda_{\mathrm{t}} \mathrm{K}_{\mathrm{t}}=0
\end{gathered}
$$

29 Denote $g_{t}=G_{t} / K_{t}$ as the share of capital allocated to public goods, $r_{t}=R_{t} /_{K_{t}}$ as the share of capital extracted by politicians, and $c_{t}=C_{t} /_{K_{t}}$ as the share of capital consumed by the households. (Chu \& Yang, 2012). 


$$
\begin{gathered}
\frac{\partial \mathcal{H}_{t}}{\partial r_{t}}=\frac{L}{\mathrm{r}_{\mathrm{t}} \mathrm{K}_{\mathrm{t}}} \mathrm{K}_{\mathrm{t}}-\lambda_{\mathrm{t}} \mathrm{K}_{\mathrm{t}}=0 \\
\frac{\partial \mathcal{H}_{t}}{\partial \hat{\mu}_{t}}=\mathrm{K}_{\mathrm{t}}\left(A-\rho-\left(1-\theta_{t}\right) i \tau_{t}-\theta_{t} i^{*} \tau_{t}^{*}-\left(\theta_{t}\right)^{2} / m\right)=\dot{\mathrm{K}}_{\mathrm{t}} \\
\frac{\partial \mathcal{H}_{t}}{\partial \lambda_{t}}=\mathrm{K}_{\mathrm{t}}\left(\mathrm{p}\left(\tau_{t}-\tilde{t_{t}}\right)+\varphi\left(\widetilde{y_{t}}-A\right)-\mathrm{g}_{\mathrm{t}}-\mathrm{r}_{\mathrm{t}}\right)=0
\end{gathered}
$$

The first order conditions with respect to $\tau_{t}, K_{t}, g_{t}, r_{t}, \hat{\mu}_{t}, \lambda_{t}$ transversality condition $\left(\lim _{t \rightarrow \infty} e^{-\rho t} \hat{\mu}_{t} K_{t}=0\right)$ and the firm problem's result, $(r=A)$, give the following result

$$
\hat{\mu}_{t} \dot{K}_{t}-\dot{\hat{\mu}}_{t} K_{t}=\hat{\mu}_{t} K_{t} \rho-(2-L)
$$

Integrating with respect to time, then $\hat{\mu}_{\mathrm{t}} \mathrm{K}_{\mathrm{t}}=(2-L) / \rho$. Substituting this into the first order conditions, choice variables will be as follows:

$$
\begin{aligned}
G_{t} & =\frac{p \rho(1-L)(1-s)}{A[1+(1-L)(1-s)]\left[A(1+m)\left(\tau_{t}-1\right)-1\right]} K_{t} \\
R_{t} & =\frac{p \rho L}{A[1+(1-L)(1-s)]\left[A(1+m)\left(\tau_{t}-1\right)-1\right]} K_{t}
\end{aligned}
$$
problem:

By substituting these equations into the first constraint of local government's

$$
\begin{gathered}
G_{t}+R_{t}=\frac{p \rho(1-s+s L)}{A[1+(1-L)(1-s)]\left[A(1+m)\left(\tau_{t}-1\right)-1\right]} K_{t} \\
=\left(p\left(\tau_{t}-\widetilde{t_{t}}\right)+\varphi\left(\widetilde{y_{t}}-A\right)\right) K_{t}
\end{gathered}
$$

By simplifying the above equation, we can find the optimal tax rate by the help of MATLAB. MATLAB gives long and complicated two roots for optimal tax rate. Under specific parameters, the first root gives plausible values as a tax rate ${ }^{30}$.

Central Government's Problem:

$$
\max _{p, \varphi} U+U^{*}
$$

subject to

$$
\mathrm{A} \tau_{t} K_{t}+\mathrm{A} \tau_{t}^{*} K_{t}^{*}=\mathrm{p}\left[\tau_{\mathrm{t}} \mathrm{K}_{\mathrm{t}}-\breve{\mathrm{T}}_{\mathrm{t}}\right]+\varphi\left[\breve{\mathrm{Y}}_{\mathrm{t}}-\mathrm{A} \mathrm{K}_{\mathrm{t}}\right]+\mathrm{p}\left[\tau_{\mathrm{t}}{ }^{*} \mathrm{~K}_{\mathrm{t}}{ }^{*}-\breve{\mathrm{T}}_{\mathrm{t}}^{*}\right]+\varphi\left[\breve{\mathrm{Y}}_{\mathrm{t}}^{*}-\mathrm{AK}_{\mathrm{t}}{ }^{*}\right]
$$




$$
p \in[0,1], \varphi \in[0,1]
$$

where $U$ and $U^{*}$ are objective functions of two citizens.

Imposing symmetric jurisdictions assumption $\left(\tau_{\mathrm{t}}=\tau_{\mathrm{t}}{ }^{*}, \mathrm{~K}_{\mathrm{t}}=\mathrm{K}_{\mathrm{t}}{ }^{*}\right)$ and the multiplication logarithm rule ${ }^{31}$ then taking the first-order condition with respect to $p$ and $\varphi$ gives the following equation:

$$
\frac{\partial \tau}{\partial p}\left[\frac{\partial \tau}{\partial \varphi}(p-A)+\tilde{y}-A\right]=\frac{\partial \tau}{\partial \varphi}\left[\frac{\partial \tau}{\partial p}(p-A)+\tau-\tilde{t}\right]
$$

By solving this equation, we can find optimal $p$ in terms of $\varphi$. By substituting optimal $p$ to the budget constraint, we are able to find optimal $\varphi$ with the help of MATLAB.

$31 \log (A * B)=\log (A)+\log (B)$. 